\title{
Faktor Yang Berhubungan Dengan Kompetensi Petani Kopi Di Desa Wisata Keseneng Kecamatan Sumowono Kabupaten Semarang Jawa Tengah
}

\section{Factors Related to the Competence of Coffee Farmers in Keseneng Tourism Village Sumowono Sub District Semarang Regency Central Java}

\author{
Yollanda Tellera Agustin ${ }^{1)}$, Wulan Sumekar ${ }^{1)}$, Tutik Dalmiyatun ${ }^{1)}$ \\ ${ }^{1)}$ Program Studi Agribisnis, Departemen Pertanian, Fakultas Peternakan dan Pertanian, \\ Universitas Diponegoro \\ Email: yollandatellera10@gmail.com
}

Submit: 12 Juli 2020, Revised: 6 Agustus 2020, Accepted: Agustus 2020

\begin{abstract}
Factors to improve the competence of farmers in developing coffee businesses need to be studied more deeply, considering the Keseneng Village status as a Tourism Village. The purposes of this research were: 1) to analyze the competence of coffee farmers in Keseneng Village, and 2) to analyze the relationship between internal and external factors with the competence of coffee farmers in Keseneng Village. This research was conducted in Keseneng Tourism Village Sumowono District Semarang Regency Central Java on August 2019. Data collection was carried out by direct interview to coffee farmers. Respondents of 32 coffee farmers were selected using purposive sampling method. Data collected was processed using the Rank Spearman correlation analysis. The competence of the coffee farmers in developing coffee businesses is in the medium category. The variables of formal education and experience of farmers were not significantly related to the competence of the farmers in developing the coffee businesses while the farmers' income (0.751) and their participation in extension activities (0.794) were significantly and positively related to that at a very strong relationship level. Social interaction of plantation communities $(0,713)$ is highly significant related with the competence of farmers at the level of strong relationship.
\end{abstract}

Keyword: Coffee; Competence and Farmer.

\begin{abstract}
ABSTRAK
Faktor-faktor untuk meningkatkan kompetensi petani dalam pengembangan usaha perlu dikaji lebih dalam, mengingat Desa Keseneng berstatus sebagai Desa Wisata. Tujuan penelitian ini adalah untuk: 1) menganalisis kompetensi petani kopi di Desa Keseneng, 2) menganalisis hubungan faktorfaktor internal dan eksternal dengan kompetensi petani kopi di Desa Keseneng. Penelitian di laksanakan pada bulan Agustus 2019 di Desa Keseneng Kecamatan Sumowono, Kabupaten Semarang. Penelitian menggunakan metode survei, metode pengumpulan data dilakukan dengan wawancara secara langsung kepada petani kopi sebagai responden. Penentuan responden dengan menggunakan metode purposive sampling sebanyak 32 responden. Metode analisis data menggunakan analisis korelasi Rank Spearman. Hasil penelitian menunjukkan bahwa petani kopi di Desa Keseneng memiliki kompetensi dalam pengembangan usaha kopi pada kategori sedang. Hasil analisis menunjukkan
\end{abstract}


peubah pendidikan formal dan pengalaman petani tidak berhubungan nyata dengan kompetensi petani dalam mengembangkan usaha kopi. Peubah penerimaan kopi $(0,751)$ dan keikutsertaan dalam kegiatan penyuluhan $(0,794)$ berhubungan nyata dan positif dengan kompetensi petani pada tingkat keeratan hubungan sangat kuat. Peubah interaksi social masyarakat perkebunan $(0,713)$ berhubungan sangat nyata dengan kompetensi petani pada tingkat keeratan hubungan kuat.

Kata Kunci :Kompetensi; Petani dan Kopi.

\section{PENDAHULUAN}

Kopi merupakan tanaman yang berasal dari subsektor perkebunan (Meylan et al., 2017; Tsai and Chen, 2017; Escola et al., 2020). Di Indonesia kopi menjadi salah satu komoditas andalan ekspor selain kakao dan kelapa sawit. Lahan perkebunan kopi di Indonesia didominasi oleh Perkebunan Rakyat (PR) yaitu sebanyak 96\% dan 4\% sisanya merupakan Perkebunan Besar Negara (PBN) dan Perkebunan Besar Swasta (PBS) (Permentan Nomor 49, 2014).

Produksi kopi di Kabupaten Semarang berada pada urutan kedua setelah Kabupaten Temanggung yang memiliki produksi tertinggi di Jawa Tengah. Kecamatan Sumowono merupakan wilayah yang berada di Kabupaten Semarang yang memiliki potensi pengembangan tanaman kopi dengan hasil produksi sebesar 621,88 ton/tahun (BPS, 2018). Salah satu desa di Kecamatan Sumowono yang membudidayakan kopi adalah Desa Keseneng, desa tersebut memiliki luas lahan pertanian bukan sawah seluas 353,65 hektar $(73 \%$ dari total luas wilayah desa) dan merupakan desa dengan luas lahan terluas ketiga setelah Desa Candiangon dan Desa Kebonagung.

Desa Keseneng berada di ketinggian 700 mdpl dengan curah hujan yang dimiliki $2.300 \mathrm{~mm} / \mathrm{tahun}$. Keadaan geografis tersebut membuat Desa Keseneng memiliki kekayaan alami yang berlimpah sehingga berpotensi untuk dikembangkan sebagai desa wisata. Objek wisata yang menjadi andalan yaitu Curug Tujuh Bidadari, pengelolaan wisata dilakukan oleh masyarakat setempat dengan menawarkan pemandangan alam yang eksotis dan harga tiket yang terjangkau, sehingga membuat wisata tersebut tidak pernah sepi penggunjung. Pesona alam yang disuguhkan kepada para penggunjung adalah adanya perkebunan kopi yang sangat luas dan berada di sepanjang perjalanan menuju lokasi wisata, hal tersebut dijadikan sebagai daya tarik guna menarik perhatian pengunjung (SosaAranda et al., 2018; Santamaría et al., 2020; Huang et al., 2020). Perkebunan kopi yang berada di Desa Keseneng merupakan perkebunan milik rakyat, kondisi wilayah yang dimiliki sangat mendukung untuk pengembangan budidaya tanaman kopi.

Perkembangan desa wisata berbasis kopi tidak hanya berada di Desa Keseneng, melainkan juga di beberapa desa sekitar yang berlokasi di Kecamatan Sumowono. Tingginya persaingan antar petani kopi menjadi permasalahan bagi petani setempat dalam proses pengembangan desa wisata berbasis kopi, secara tidak langsung pengaruh tersebut dapat berdampak pada kesejahterahan petani. Perlu adanya pengelolaan terutama berkaitan dengan kualitas sumber daya manusia yaitu petani, sehingga diharapkan dapat meningkatkan tingkat kompetensi petani dalam mengelola produksi kopi guna menuju perkembangan desa wisata yang memiliki keunggulan tersendiri (Vicol et al., 2018; Dufour et al., 2019; Durand-Bessart et al., 2020). Selama ini petani langsung menjual hasil produksi kepada para tengkulak, hal tersebut dikarenakan petani belum memiliki kemampuan dalam mengelola kopi pada proses pasca panen. Upaya peningkatan kompetensi petani diharapkan dapat menjadi evaluasi dan sumber perencanaan untuk melakukan pengembangan usaha kopi menjadi produk unggulan, sehingga akan memberi nilai 
tambah bagi desa wisata berbasis kopi di Desa Keseneng.

Potensi tanaman kopi yang berada di Desa Keseneng belum dapat dimanfaatkan secara optimal oleh petani. Kompetensi petani menjadi kendala tersendiri dalam proses pengelolaan usaha serta sulit untuk melakukan penanganan terhadap permasalahan yang timbul mulai dari kegiatan di lahan hinga pemasaran, sehingga perlu adanya peran petani secara konkrit seperti melakukan inovasi baru, adopsi teknologi, menerapkan pengolahan dengan manajemen yang terstruktur, pengembangan usaha produk untuk meningkatkan profit (Eanes et al., 2019; Fischer et al., 2019; Hong and Sun, 2020). Kompetensi menjadi tolak ukur keberhasilkan petani dalam menjalankan usaha dalam bidang pertanian. Penelitian terdahulu oleh Zakaria et al. (2017) menyatakan terdapat tiga strategi yang sangat penting dalam mengembangkan usaha tani kopi yaitu mengembangkan pengolahan hasil usaha tani, meningkatkan keterampilan teknis usaha tani, dan pemberdayaan kelompok tani untuk lebih meningkatkan usahanya. Faktor-faktor untuk meningkatkan kompetensi petani dalam pengembangan usaha kopi khususnya dalam bidang pengolahan hasil menjadi produk unggulan perlu dikaji lebih dalam, mengingat Desa Keseneng berstatus sebagai Desa Wisata.

Uraian di atas yang menjadi latar belakang penulis untuk meneliti faktor yang berhubungan kompetensi petani di Desa Wisata Keseneng Kecamatan Sumowono Kabupaten Semarang Jawa Tengah. Adapun tujuan penelitian ini antara lain: 1) menganalisis kompetensi petani kopi di Desa Keseneng, 2) menganalisis hubungan faktor-faktor internal dan eksternal dengan kompetensi petani kopi di Desa Keseneng.

\section{METODE PENELITIAN}

Penelitian telah dilaksanakan pada bulan Agustus-September 2019 yang dilakukan di Desa Keseneng Kecamatan Sumowono Kabupaten Semarang Jawa Tengah. Penelitian menggunakan metode survei, metode pengumpulan data dilakukan dengan wawancara secara langsung kepada petani kopi sebagai responden. Penentuan responden dengan menggunakan metode purposive sampling sebanyak 32 responden yaitu petani kopi yang melakukan kegiatan usahatani kopi dengan aktif dan memiliki lahan kopi.

Data yang dikumpulkan terdiri dari data primer dan data sekunder. Data primer terdiri dari informasi yang dibutuhkan seperti identitas responden, faktor komptensi dan kompetensi petani. Data primer diperoleh dengan mendatangi dan melakukan wawancara terhadap responden dengan berpedoman pada kuesioner. Data sekunder terdiri dari informasi tambahan berupa data statistik, pustaka terkait dan data pendukung lainnya yang diperoleh dari dokumentasi dan dokumen pelengkap yang diterbitkan oleh instansi terkait. Data yang diperoleh kemudian ditabulasi, lalu dianalisis.

\section{Analisis Data.}

Analisis korelasi yang digunakan adalah korelasi Rank-Spearman dengan bantuan program SPSS 23. Analisis korelasi ini dilakukan dengan tujuan agar dapat mengetahui hubungan antara faktor-faktor dengan kompetensi petani kopi di Desa Keseneng. Adapun rumus koefisien korelasi Rank Spearman sebagai berikut (Kurniawan dan Yuniarto, 2016):

$$
\mathrm{r}_{\mathrm{s}}=1-\frac{6 \sum d^{2}}{n\left(n^{2}-1\right)}
$$

Keterangan:

$\mathrm{R}$ : koefisien korelasi Rank-Spearman

$\mathrm{d}$ : selisih dalam rangking.

$\mathrm{n}$ : banyaknya pasangan dalam Rank

Pemberian skor ditentukan menggunakan pembagian interval kelas menjadi tiga kategorisasi (Azwar, 2012), dimana didapatkan hasil:

1. Pendidikan Formal (X1): kategori tinggi $(\mathrm{X} 1>$ Mean $+\mathrm{Sd}=\mathrm{X} 1>2,55)$, sedang $($ Mean $-\mathrm{Sd} \leq \mathrm{X} 1 \leq$ Mean $+\mathrm{Sd}=1,27 \leq$ $\mathrm{X} 1 \leq 2,55)$, dan rendah $(\mathrm{X} 1<$ Mean $\mathrm{Sd}=\mathrm{X} 1<1,27)$

2. Pengalaman Petani (X2): kategori tinggi $(\mathrm{X} 2>$ Mean $+\mathrm{Sd}=\mathrm{X} 2>4,28)$, sedang $($ Mean $-\mathrm{Sd} \leq \mathrm{X} 2 \leq$ Mean $+\mathrm{Sd}=1,85 \leq$ 
$\mathrm{X} 2 \leq 4,28)$, dan rendah $(\mathrm{X} 2<$ Mean $\mathrm{Sd}=\mathrm{X} 2<1,85)$.

3. Penerimaan Kopi (X3): kategori tinggi $(\mathrm{X} 3>$ Mean $+\mathrm{Sd}=\mathrm{X} 3>6,40)$, sedang (Mean $-\mathrm{Sd} \leq \mathrm{X} 3 \leq$ Mean $+\mathrm{Sd}=2,85 \leq$ $\mathrm{X} 3 \leq 6,40)$, dan rendah $(\mathrm{X} 3<$ Mean $\mathrm{Sd}=\mathrm{X} 3<2,85)$.

4. Keikutsertaan dalam Kegiatan Penyuluhan (X4): $(\mathrm{X} 4>$ Mean $+\mathrm{Sd}=$ $\mathrm{X} 4>14,09)$, sedang (Mean $-\mathrm{Sd} \leq \mathrm{X} 4 \leq$ Mean $+\mathrm{Sd}=9,04 \leq \mathrm{X} 4 \leq 14,09)$, dan rendah $(\mathrm{X} 4<$ Mean $-\mathrm{Sd}=\mathrm{X} 4<9,04)$.
5. Interaksi Sosial Masyarakat Perkebunan (X5): kategori tinggi (X5 > Mean $+\mathrm{Sd}$ $=\mathrm{X} 5>6,94)$, sedang $($ Mean $-\mathrm{Sd} \leq \mathrm{X} 5$ $\leq$ Mean $+\mathrm{Sd}=3,75 \leq \mathrm{X} 5 \leq 6,94)$, dan rendah $(\mathrm{X} 5<$ Mean $-\mathrm{Sd}=\mathrm{X} 5<3,75)$.

6. Kompetensi Petani (Y): $(\mathrm{Y}>$ Mean + $\mathrm{Sd}=\mathrm{Y}>65,56)$, sedang $($ Mean $-\mathrm{Sd} \leq$ $\mathrm{Y} \leq$ Mean $+\mathrm{Sd}=46,63 \leq \mathrm{Y} \leq 65,56)$, dan rendah $(\mathrm{Y}<$ Mean $-\mathrm{Sd}=\mathrm{Y}<$ $46,63)$.

Tabel 1. Sebaran Petani Responden berdasarkan Kategori Variabel X dan Y Petani Kopi di Desa Wisata Keseneng $(n=32)$

\begin{tabular}{llrr}
\hline Var. & Ket. & Jumlah & Persentase \\
\hline & & (jiwa) & $(\%)$ \\
X1 & Tinggi & 3 & 9.38 \\
Pendidikan formal & Sedang & 22 & 68.75 \\
& Rendah & 7 & 21.88 \\
X2 & Tinggi & 4 & 12.50 \\
Pengalaman petani & Sedang & 24 & 75.00 \\
& Rendah & 4 & 12.50 \\
X3 & Tinggi & 6 & 18.75 \\
Penerimaan kopi & Sedang & 22 & 68.75 \\
& Rendah & 4 & 12.50 \\
X4 & Tinggi & 4 & 12.50 \\
Keikutsertaan dalam kegiatan penyuluhan & Sedang & 20 & 62.50 \\
& Rendah & 8 & 25.00 \\
X5 & Tinggi & 8 & 25.00 \\
Interaksi sosial masyarakat perkebunan & Sedang & 19 & 59.38 \\
& Rendah & 5 & 11.62 \\
Y & Tinggi & 6 & 18.75 \\
Kompetensi petani kopi & Sedang & 20 & 62.50 \\
& Rendah & 6 & 18.75 \\
\hline
\end{tabular}

\section{HASIL DAN PEMBAHASAN}

\section{Pendidikan Formal (X1).}

Petani pada tingkat pendidikan formal kategori rendah $(21,88 \%)$ terdiri dari petani yang tidak lulus SD juga petani yang tidak bersekolah. Mayoritas petani kopi pada tingkat pendidikan formal kategori sedang $(68,75 \%)$ terdiri dari petani yang bersekolah hingga tamat SD saja. Rendahnya tingkat pendidikan petani menghambat proses transfer ilmu dan teknologi terbaru pertanian. Petani cenderung mempertahankan pengetahuan yang mereka peroleh dari generasi sebelumnya atau orang tuanya dalam mengelola usahatani, tanpa ada pemikiran lebih jauh untuk mengembangkan usahatani kopi. Menurut Waris et al. (2015), menyatakan bahwa petani yang berpendidikan lebih tinggi relatif lebih cepat memahami sesuatu hal baru, sehingga dapat melaksanakan adopsi inovasi dengan cepat. Hal ini juga sesuai dengan pendapat Nazaruddin dan Anwarudin (2019), yang menyatakan bahwa pendidikan formal dapat mempengaruhi tingkat berpikir 
dalam mengambil keputusan maupun dalam bertindak.

Petani kopi dengan tingkat pendidikan formal kategori tinggi $(9,38 \%)$, terdiri dari petani-petani yang tamat SLTP dan tamat SLTA. Tidak ada petani responden yang melanjutkan pendidikan hingga perguruan tinggi. Faktor yang mempengaruhi dari sisi sosial yakni pengaruh lingkungan masyarakat desa Keseneng. Pemuda-pemudi desa Keseneng cenderung lebih memilih untuk langsung bekerja demi membantu orang tua memenuhi kebutuhan hidup. Selain itu dari sisi ekonomi, pendapatan petani hanya cukup unutk memenuhi kebutuhan hidup petani. Pemuda-pemudi desa Keseneng yang melanjutkan perguruan tinggi tidak tertarik mengambil konsentrasi bidang pertanian, melainkan bidang kesehatan. Hal ini sesuai dengan pendapat Meliasari et al. (2017), yang menyatakan bahwa hal yang menyebabkan pemuda lebih tertarik di luar bidang pertanian adalah faktor lingkungan yang mayoritas pemudanya bekerja sebagai buruh pabrik di kota rantau, karena pendapatan yang diperoleh tetap dan gaji yang dihasilkan lebih cukup.

Pengalaman Petani (X2). Petani pada pengalaman berusahatani kopi kategori rendah $(12,50 \%)$ merupakan petani yang memiliki pengalaman kurang 10 tahun terdiri dari petani yang sebelumnya lebih konsentrasi di sektor tanaman pangan dan penduduk yang dulunya merantau. Petani yang dulunya merantau untuk mengumpulkan modal di kota besar, setelah modal mereka terkumpul digunakan untuk membeli lahan di desa dan menjadi petani. Mayoritas petani kopi pada pengalaman usahatani kategori sedang $(75 \%)$ memiliki lahan sawah juga lahan perkebunan. Sebagian petani kopi juga merupakan petani yang memiliki mata pencaharian utama berusahatani tanaman semusim seperti padi, daun bawang, terong, cabai dan lain sebagainya, sehingga berusahatani kopi hanya dijadikan penghasilan sampingan atau tambahan saja. Sisanya petani pada pengalaman usahatani kategori tinggi (12,50\%) merupakan petani kopi tulen atau petani yang sejak kecil sudah berusahatani kopi. Petani belajar bertani umumnya sejak masih kecil dari orang tuanya dengan cara membiasakan mereka menggarap lahan milik orang tuanya. Umumnya teknik budidaya kopi yang dilakukan tidak jauh berbeda dengan yang diajarkan orang tua para petani atau turuntemurun, sehingga belum ada hasil perbedaan signifikan yang terlihat.

Petani kopi yang berhasil biasanya memiliki pengetahuan tentang kopi lebih mendalam, dan secara praktek juga lebih siap dalam menghadapi berbagi permasalahan dalam usahataninya. Petani kopi di Desa Keseneng sadar akan pentingnya pemupukan menggunakan bahan organik seperti, hasil kotoran ternak dan limbah tanaman yang dikomposkan. Petani juga memiliki kemampuan yang baik dalam melakukan pengolahan hasil kopi menjadi bubuk kopi. Keterampilan petani dalam melakukan pengolahan kopi secara kering maupun pengolahan setengah basah sebelum dijual ke tengkulak.

Pengalaman usahatani saja tidak cukup dalam melakukan pengembangan usaha kopi. Petani kopi di Desa Keseneng yang memiliki pengalaman usahatani lama, jauh lebih terbuka dalam menyikapi informasi dan teknologi baru dalam mengembangkan usaha kopi, juga memiliki kemampuan lebih baik dalam mengusahakan kopi. Hanya saja petani dengan pengalaman lebih lama belum tentu memiliki motivasi tinggi untuk mengembangkan usaha kopi.

Penerimaan Kopi (X3). Petani pada tingkat penerimaan kategori rendah $(18,75 \%)$ merupakan petani dengan penerimaan kopi kurang dari Rp 5.000.000 per tahun yang memiliki lahan perkebunan relatif sempit seluas $\leq 0,25$ ha. Mayoritas petani kopi di Desa Keseneng pada kategori sedang $(68,75 \%)$ yang merupakan petani dengan penerimaan kopi antara Rp 5.000.000 - Rp 30.000.000 per tahun. Sebagian kecil petani dengan tingkat penerimaan tinggi $(12,50 \%)$ meupakan petani dengan penerimaan kopi diatas $\mathrm{Rp} 30.000 .000$ per tahun. Petani dengan penerimaan kopi tinggi mayoritas memiliki lahan lebih dari 0,25 
ha dan menjadikan kopi sebagi penghasilan utama.

Penerimaan kopi tersebut merupakan hasil panen yang belum dikurangi dengan biaya operasional budidaya, sedangkan panen kopi di Desa Keseneng hanya setahun sekali biasanya pada pertengahan tahun yaitu bulan Juli-Agustus. Bagi petani yang menjadikan kopi sebagai penghasilan utama, jumlah tersebut hanya cukup untuk kebutuhan pokok saja. Menurut lampiran Keputusan Gubernur Jawa Tengah Nomor 560/68 tahun 2018 berikut UMK Kota Semarang tahun 2019 adalah Rp. 2.498.587.53. Jika dikalkulasi dalam satu tahun seharusnya penerimaan petani yang layak sebesar Rp 29.983.050.36. Hanya sebagian kecil petani di Desa Keseneng yang pendapatan kopi di atas UMR atau dinyatakan layak.

Berdasarkan hasil lapangan didapatkan hasil bahwa hampir seluruh petani kopi tidak merasakan perubahan signifikan terhadap penerimaan sebelum dan sesudah desa tersebut menjadi desa wisata. Hal ini terlihat bahwa keterbatasan pengetahuan petani dalam memanfaatkan peluang pasar masih rendah. Seharusnya dengan status desa wisata, petani dapat memotong jalur pemasaran langsung ke konsumen yaitu pengunjung desa wisata sehingga pemasaran berjalan secara efektif. Menurut Rayuddin (2010), semakin pendek jalur tataniaga kopi dari petani produsen ke pabrik, maka semakin efektif jalur pemasaran.

Selain itu penambahan nilai jual dengan melakukan pengolahan hasil kopi menjadi produk unggulan desa wisata seharusnya bisa meningkatkan penerimaan petani. Pembuatan produk unggulan dari hasil pengolahan kopi dapat meningkatkan penerimaan petani. Petani mampu melakukan pengolahan kopi menjadi kopi bubuk, namun hanya sebagai konsumsi pribadi. Hal ini sesuai dengan pendapat Priantara et al. (2016) yang menyatakan bahwa pembentukan nilai tambah paling besar yaitu pada proses pengolahan nilai tambah kopi bubuk dengan rasio nilai tambah sebesar $92 \%$.

\section{Keikutsertaan dalam Kegiatan Penyuluhan} (X4).

Berdasarkan Tabel 1. diketahui mayoritas kegiatan penyuluhan di Desa Keseneng 135 pada kategori sedang yaitu sebanyak 20 petani $(62,50 \%)$. Kegiatan penyuluhan pada kategori rendah sebanyak 8 petani (25\%) dan kategori tinggi sebanyak 4 petani $(12,50 \%)$. Hal ini berarti bahawa keikutsertaan dalam kegiatan penyuluhan di Desa Keseneng sedang. Menurut hasil di lapangan didapatkan hasil bahwa kegiatan penyuluhan hanya 3 kali dalam setahun, bahkan mayoritas petani menyebutkan tidak ada kegiatan penyuluhan dan tidak pernah mengikuti kegiatan penyuluhan. Ketidakhadiran petani dalam kegitan penyuluhan menandakan bahwa petani belum mengerti seberapa pentingnya kegiatan penyuluhan.

Rata-rata petani yang mengikuti kegiatan penyuluhan merupakan masyarakat yang memiliki jabatan penting di desa dan mereka aktif mencari informasi terbaru tentang pertanian. Penyuluh belum bisa merangkul seluruh petani desa Keseneng dalam rangka pembangunan desa di sektor pertanian. Hal ini dapat dilihat dari ketidakhadiran petani dalam kegiatan penyuluhan karena petani belum sepenuhnya percaya dengan penyuluh. Hal ini sesuai dengan pendapat Allen et al. (2015), yang menyatakan bahwa kendala yang dihadapi penyuluh pertanian adalah partisipasi petani dalam kegiatan penyuluhan yang masih kurang.

Kegiatan penyuluhan dalam setahun terakhir antara lain; penyuluhan tentang budidaya alpukat, budidaya padi dan pembagian bibit kopi. Penyuluhan yang berhubungan dengan materi kopi sebatas mengenai budidaya dan pembagian bibit kopi siap tanam. Penyuluhan tentang budidaya kopi juga dilaksanakan di desa Keseneng beberapa puluh tahun yang lalu, sehingga belum ada informasi terbaru tentang budidaya yang baik dan benar. Hal ini sesuai dengan pendapat Mahyuda et al. (2018), yang menyatakan bahwa semestinya penambahan pengetahuan dan pemahaman petani dapat dilakukan dengan meningkatkan intensitas mengikuti pendidikan nonformal, baik berupa pelatihan, khursus tani. Sebagian petani menanam bibit yang diberikan penyuluh, sebagian lagi tidak 
menanam bibit tersebut. Hal ini terjadi sebab prinsip beberapa petani usia tua dengan pengalaman yang cukup lama dalam berusahatani kopi tidak percaya dengan penyuluh dan menganggap bibit kopi hasil setek dari kebun mereka sendiri lebih baik. Hal ini sesuai dengan pendapat Allen et al. (2015), dimana petani tidak langsung menerapkan materi yang penyuluh berikan karena petani ingin bukti nyata terhadap apa yang disampaikan penyuluh kepada petani.

Belum ada penyuluhan tentang pengembangan usaha kopi di Desa Keseneng hingga saat ini. Beberapa petani kopi yang aktif mencari informasi sudah berusaha menghubungi penyuluh untuk meminta bantuan alat teknologi pengolahan kopi tepat guna terbaru, namun belum ada respon lanjutan hingga saat ini. Menurut Pratiwi (2016), peningkatan kesadaran penanganan pasca panen yang tepat menjadi alternatif prioritas utama, selanjutnya pemberian bantuan teknologi serta pendampingan pengolahan dan terakhir pelatihan inovasi dan diversifikasi olahan kopi.

\section{Interaksi Sosial Masyarakat Perkebunan (X5).}

Berdasarkan Tabel 1. diketahui bahwa mayoritas petani di Desa Keseneng memiliki interaksi sosial masyarakat perkebunan dalam kategori sedang yaitu terdapat 19 petani $(59,38 \%)$. Interaksi sosial masyarakat perkebunan dalam kategori rendah terdapat 5 petani $(11,62 \%)$, sedangkan interaksi sosial masyarakat perkebunan dalam kategori tinggi terdapat 8 petani $(25,00 \%)$. Hal ini berarti bahwa petani kopi di Desa Keseneng interaksi sosial masyarakat perkebunan sedang. Petani mengakses informasi mengenai syarat mutu kopi, pengolahan hasil kopi dan pemasaran dari hasil interaksi antar petani, interaksi dengan penyuluh dan pedagang saja.

Interaksi antar petani mengenai syarat mutu kopi hanya mengenai panen "petik merah", yaitu pemanenan buah kopi yang berwarna merah saja untuk mempertahankan kualitas kopi. Hanya seorang petani yang merupakan ketua kelompok tani memiliki akses dekat dengan penyuluh. Hal ini disebabkan petani tersebut memiliki hubungan yang baik atau akrab dengan penyuluh, sehingga apabila terdapat permasalah mengenai pertanian langsung mengadu ke penyuluh untuk mendapatkan solusi terbaik. Hal ini sesuai dengan pendapat Malta (2016), diperlukan keaktifan mencari informasi dan interaksi dengan penyuluh dalam pengambilan keputusan agar keberhasilan usahatani tercapai.

Akses informasi antar petani mengenai teknologi pengolahan hasil kopi sebatas pada pengolahan hasil kopi secara kering dan cara setengah basah. Teknologi pengolahan kopi yang tersedia di Desa Keseneng hanya berupa mesin penggiling kopi dimana hampir semua petani sudah punya mesin tersebut dan mesin selep yang hanya dimiliki beberapa petani kopi yang sudah sukses. Menurut Muhibuddin et al. (2015), petani sukses merupakan salah satu sumber informasi yang tersedia dan mudah diakses oleh petani. Petani yang menumpang mesin selep ke petani lain dikenai biaya $\mathrm{Rp} 5.000$ per $\mathrm{kg}$ kopi yang telah dijemur. Seluruh petani di Desa Keseneng sudah mampu mengolah kopi menjadi kopi bubuk sejak masih kecil, karena pengatahuan itu sudah diajarkan secara turun-temurun oleh keluarga petani. Petani hanya mengolah sebagian kecil hasil panen menjadi bubuk kopi yang hanya dijadikan konsumsi pribadi. Hal ini sesuai dengan pendapat Romano (2009), proses pengelolaan pertanian baik budidaya maupun pasca panen lebih dipengaruhi oleh pengetahuan dari orang tua yang ditransfer kepada anaknya.

Interaksi dengan pedagang mengenai syarat mutu kopi lebih terbatas, karena pedagang hanya menampung kopi yang dijual baik dalam keadaan basah ataupun yang sudah mengalami proses pengolahan. Peluang ini dimanfaatkan dengan baik oleh pedagang. Hasil kopi yang dibeli pedagang dari petani, kemudian disortasi sesuai tingkat kualitas kopi sebelum dijual kembali ke pabrik maupun pedagang besar lainnya sehingga pedagang mendapatkan keuntungan. Interaksi petani dengan pedagang juga sebatas mengakses informasi harga. 
Petani bersikap pasif, yaitu petani hanya bisa menerima saat harga ditentukan oleh pedagang tersebut. Sejauh ini, pedagang kopi atau biasa disebut tengkulak di Desa Keseneng hanya satu orang.

Kesadaran petani memanfaatkan tempat wisata di desanya sebagai tempat dimana mereka dapat menjual hasil kopi olahan juga masih kurang. Beberapa sudah mencoba menjual kopi dalam bentuk olahan kopi bubuk apabila ada event desa wisata ataupum apabila sebelumnya sudah ada yang memesan kopi bubuk petani. Sebagian kecil petani sudah memiliki inisiatif menjual kopi sedu yang dihidangkan dengan gula aren gigit, namun masih belum terealisasi hingga saat ini. Petani belum tahu tata cara promosi yang tepat, karena mereka masih bersifat pasif menunggu pembeli yang datang. Hasil interaksi sosial masyarakat perkebunan belum berdampak besar dalam aspek pemasaran, sehingga petani tidak mempunyai inovasi dalam pengembangan usaha kopi. Hal ini sesuai dengan pendapat Pertiwi dan Saleh (2010), semakin tinggi tingkat interaksi sosial masyarakat petani, maka semakin mudah pula proses difusi dan adopsi inovasi berlangsung.

Kelompok tani di Desa Keseneng dapat dikatakan aktif sebatas untuk menyalurkan bantuan saja. Beberapa petani beranggapan tidak ada kelompok tani, sedangkan sebagian lagi mengaku hanya memiliki kartu identitas anggota kelompok tani. Berdasarkan hasil wawancara dengan Ketua Kelompok Tani tentang peran kelompok tani sejauh mana, beliau menyatakan bahwa "Peran kelompok tani di Desa Keseneng hanya sebatas menyalurkan bantuan pemerintah jika ada, sebelebihnya saya tidak paham saya sebagai Ketua Kelompok Tani harus bagaimana". Beberapa petani sangat berharap kelompok tani di Desa Keseneng aktif, agar dapat membantu mengatasi permasalahan petani dalam sektor petanian. Hal ini sesuai dengan pendapat Muhibuddin et al. (2015) yang menyatakan bahwa salah satu penyebab tingkat keterlibatan petani dalam mengikuti kegiatan kelompoktani rendah disebabkan yaitu kelompoktani sudah tidak aktif dan kelompoktani aktif bila adanya bantuan dari pihak luar.
Mahasiswa yang melakukan penelitian di Desa Keseneng biasanya mengkaji tentang desa wisata bukan mengenai sektor pertanian maupun perkebunan. Hampir setahun dua kali Desa Keseneng menampung mahasiswa yang melaksanakan program Kuliah Kerja Nyata (KKN) dari beberapa Universitas di Semarang. Mahasiswa KKN sudah pernah membantu masyarakat mengembangkan usaha ketela menjadi produk, namun bersifat sementara dan tidak ada tindak lanjut secara intensif oleh masyarakat desa. LSM juga belum ada yang membantu dalam pengembangan usaha kopi. Hal ini sesuai dengan pendapat Muhibuddin et al. (2015), tingkat interaksi petani meliputi interaksi dengan penyuluh, interaksi antar petani dan interaksi dengan pedagang berada pada skor sedang, sedangkan skor rendah meliputi keterlibatan kelompok tani, interaksi dengan mahasiswa dan interaksi dengan LSM.

\section{Kompetensi Petani Kopi dalam Pengembangan Usaha Kopi ( $Y$ ).}

Berdasarkan Tabel 1. diketahui bahwa mayoritas kompetensi petani kopi di desa Keseneng dalam mengembangkan usaha kopi pada kategori sedang yaitu sebanyak 20 orang $(62,50 \%)$. Kompetensi petani dalam mengembangkan usaha kopi pada kategori rendah sebanyak 6 orang $(18,75 \%)$ dan pada kategori tinggi sebanyak 6 orang $(18,75 \%)$. Hal ini berarti bahwa petani kopi di Desa Keseneng memiliki kompetensi dalam pengembangan usaha kopi sedang.

\section{Perilaku Petani.}

Perilaku petani mengenali potensi kopi dalam pengembangan usaha kopi bila ditinjau dari pengetahuan masih kurang, namun petani sangat setuju apabila ada pengembangan usaha kopi. Petani kopi di Desa Keseneng tidak memiliki pengetahuan ragam inovasi dalam mengembangkan produk kopi, sehingga dapat dikatakan petani belum terampil dalam memanfaatkan potensi kopi untuk pengembangan usaha kopi. Menurut Purnawanto (2010), penguasaan seseorang atas keterampilan dinilai berdasarkan kedalamannya (depth) dan variasinya 
(variance). Hal ini sesuai dengan pendapat Yuantari et al., (2013), yang menyatakan bahwa perilaku seseorang dipengaruhi oleh tingkat pengetahuan, dimana apabila pengetahuan petani sudah baik harapannya akan diterapkan pada praktiknya seharihari

Perilaku petani dalam mengetahui syarat mutu kopi sesuai SNI masih kurang. Petani yang berpengalaman beranggapan dengan mereka memanen buah kopi dengan cara "petik merah" berarti buah kopi yang dihasilkan kualitasnya sudah baik. Menurut Reijntjes et al., (2011), pengetahuan petani terbatas pada apa yang mereka pahami berdasarkan pengalaman mereka pada masa lalu. Petani ragu-ragu untuk mempelajari syarat mutu kopi sesuai SNI, karena mereka tidak mengetahui seberapa penting bagi mereka untuk belajar syarat mutu kopi sesuai SNI. Belum ada peran penyuluh ataupun kelompok tani dalam membantu petani memahami syarat mutu kopi hingga mereka menjadi mahir/ terampil. Hal ini tidak lepas juga karena tidak adanya tuntutan pasar. Pedagang mengambil peluang tentang ketidaktahuan petani untuk melakukan sortasi sesuai syarat mutu SNI, sehingga pedagang dapat menjual kopi petani ke pedagang yang lebih besar atau pabrik dengan harga yang lebih layak. Perilaku petani dalam mempelajari pengolahan kopi secara kering sudah baik. Petani setuju untuk melakukan pengolahan kering terlebih dahulu sebelum dijual, karena dapat menaikkan harga dari Rp 5.000.- menjadi Rp 21.000.-. Proses pengolahan kopi secara kering tidak terlalu rumit sehingga dapat dikatakan petani sudah mahir/ terampil melakukan hal tersebut. Sebagian petani juga sudah melakukan pengolahan hasil kopi secara setengah basah. Namun perilaku petani dalam mempelajari pengolahan kopi secara basah masih rendah. Petani tidak setuju apabila hasil panen kopi diolah secara basah terlebih dahulu sebelum dijual. Hal ini disebabkan oleh pengolahan kopi secara basah memakan waktu yang lama, selain itu petani keterbatasan teknologi pengolahan basah menjadi hambatan bagi petani. Faktor kebutuhan menjadikan petani ingin segera menjual hasil kopi tanpa melakukan pengolahan secara basah. Petani tidak terampil dalam melakukan pengolahan kopi secara basah.

Perilaku petani dalam mempelajari pemasaran kopi dengan mempertimbangkan 4P (product. place. price. promotion) masih kurang. Hal ini terlihat dari sifat pasif yang dimiliki petani, yang berarti petani hanya menunggu pembeli datang dalam menjual kopi. Petani belum mengusahakan untuk membuat produk unggulan desa wisata yang dapat dijual langsung ke pengunjung tempat wisata dengan harga yang lebih tinggi. Latar belakang pendidikan petani mayoritas lulusan SD, begitu juga belum adanya pelatihan dalam pengemgembangan usaha kopi menjadikan petani tidak memiliki keberanian dalam melakukan promosi. Petani dalam memasarkan kopi dapat dikatakan belum mahir/ terampil. Hal ini sesuai dengan pendapat Manyamsari dan Mujiburrahmad (2014) yang menyatakan bahwa pelatihan berhubungan dengan peningkatan penerimaan suatu informasi, sehingga membuka wawasan pengetahuan dan keterampilan petani.

\section{Kemampuan Petani.}

Petani mampu mengenali potensi kopi di Desa Keseneng menjadi produk unggulan desa wisata. Hasil kondisi di lapangan menunjukkan bahwa petani mampu mengolah kopi menjadi produk, terlihat dari sebagian besar petani mampu mengolah kopi menjadi produk olahan, seperti bubuk kopi. Petani belum mampu menyeleksi buah kopi sesuai syarat mutu kopi sesuai SNI. Ketidakmampuan ini disebabkan oleh pengetahuan petani yang rendah mengenai syarat mutu kopi sesuai SNI. Hal ini juga dapat dilihat dari interaksi petani dalam mengakses informasi tersebut belum maksimal. Mayoritas petani sudah sangat mampu mengolah hasil kopi dengan cara kering maupun setengah basah, namun petani belum mampu mengolah hasil kopi secara basah. Berdasarkan aspek 
pemasaran, petani belum mampu melakukan pemasaran dengan mempertimbangkan 4P (product, price, place, promotion). Petani sebatas mampu membuat produk olahan kopi yang potensi menjadi produk unggulan desa wisata tanpa mampu mempromosikan. Petani menjual hasil panen dan olahan kopi ke tengkulak secara langsung tanpa melakukan penawaran dan bersifat menerima ketentuan harga jual yang diinginkan tengkulak yang relatif murah.

Motivasi Petani. Tidak ada petani yang memiliki motivasi rendah. Hal ini terlihat bahwa alasan mereka berusahatani kopi sebatas melanjutkan warisan orang tua para petani dalam mendapatkan penghasilan. Menurut Suprayitno et al. (2012), tujuan dari setiap petani adalah meningkatkan penerimaan untuk memenuhi kebutuhan rumah tangga. Sebagian kecil petani yang sadar dan yakin bahwa mereka mampu melakukan usahatani kopi dengan baik. Petani tersebut adalah petani yang memiliki pengalaman paling lama dari petani lainya. Hal ini berarti bahwa sebagian besar petani hanya sekadar memenuhi kebutuhan pokok, dan sebagian kecil petani sudah mencapai kebutuhan aktualisasi diri. Menurut Teori Maslow dalam Robbins and Judge (2008), motivasi tertinggi apabila seseorang memiliki kebutuhan aktualisasi diri, yaitu dorongan untuk menjadi seseorang yang cakap dalam meliputi pertumbuhan, pencapaian potensi seseorang dan pemenuhan diri sendiri. Kesadaran petani dalam mengembangkan usaha kopi juga masih kurang. Hanya petani yang tergabung sebagai pengurus desa wisata yang memiliki kesadaran untuk mengembangkan usaha kopi. Contohnya seperti inisiatif mereka menjual kopi sedu yang disajikan dengan gula aren gigit yang sedang mereka coba usahakan untuk direalisasikan pada akhir tahun 2019.

Tabel 2. Korelasi Faktor Internal dan Eksternal dengan Kompetensi Petani 2019

\begin{tabular}{llll}
\hline \hline No & \multicolumn{1}{c}{ Faktor Internal dan Eksternal } & Kompetensi & \\
\hline & & Koef. & $\mathrm{P}$ \\
\hline 1 & Pendidikan Formal(X1) & .299 & .096 \\
2 & Pengalaman Petani (X2) & .191 & .294 \\
3 & Penerimaan Kopi (X3) & $\mathbf{. 7 5 1} * *$ & .000 \\
4 & Keikutsertaan dalam Keg. Penyuluhan (X4) & $\mathbf{. 7 9 4} * *$ & .000 \\
5 & Interaksi Sosial Masyarakat Perkebunan(X5) & $\mathbf{. 7 1 3} * *$ & .000 \\
\hline
\end{tabular}

$\mathrm{n}=32$ orang; $\mathrm{p}=$ peluang kesalahan (galat)

** Berhubungan sangat nyata pada $\mathrm{a}=0.01$

* Berhubungan nyata pada $\mathrm{a}=0.05$

\section{Hubungan Faktor-Faktor dengan Kompetensi Petani dalam Pengembangan Usaha Kopi.}

Berdasarkan hasil olah data SPSS 23 pada Tabel 2. diketahui bahwa peubah pendidikan formal dan pengalaman petani tidak berhubungan nyata dengan kompetensi petani. Peubah penerimaan kopi $(0,751)$ dan keikutsertaan dalam kegiatan penyuluhan $(0,794)$ berhubungan nyata dan positif dengan tingkat keeratan hubungan sangat kuat. Peubah interaksi sosial masyarakat perkebunan $(0,713)$ berhubungan sangat nyata dengan kompetensi petani dengan tingkat keeratan hubungan kuat.
Analisis data Tabel 2. menunjukkan bahwa pendidikan formal tidak berhubungan nyata dengan kompetensi petani dalam mengembangkan usaha kopi. Hal ini tidak terlepas dari kondisi petani yang mayoritas pendidikan formal petani hanya sampai lulus SD. Pengetahuan yang diterima petani juga sebatas pengetahuan yang didapatkan dari orang tua mereka secara turun-menurun tanpa pembaharuan. Pengetahuan tersebut juga masih diterapkan oleh petani dalam berusahatani kopi hingga saat ini. Pendidikan formal petani yang rendah, 
juga mengakibatkan keinginan petani untuk mempelajari hal baru dalam rangka meningkatkan kompetensi petani rendah pula. Pengetahuan petani yang terbatas terkadang menimbulkan ketidapercayaan diri petani untuk mencoba hal - hal baru, padahal petani mampu. Hal ini sesuai dengan pendapat Anantanyu (2011) yang menyatakan bahwa proses pendidikan merupakan upaya mengubah sikap petani dalam membangkitkan gairah serta kepercayaan akan kemampuan petani sendiri. Menurut Manyamsari dan Mujiburrahmad (2014), pendidikan merupakan proses belajar bagi petani mengenai berbagai hal yang berkaitan dengan upaya peningkatan taraf hidup petani.

Analisis data Tabel 2. menunjukkan bahwa pengalaman petani tidak berhubungan nyata dengan kompetensi petani dalam mengembangkan usaha kopi. Hal ini juga tidak terlepas dari kondisi mayoritas petani memiliki pengalaman usahatani kopi lebih dari 20 tahun, dimana selama kurun waktu tersebut petani tidak mendapatkan penambahan pengetahuan mengenai informasi dan teknologi yang memadai dalam hal pengembangan usaha kopi. Petani kopi mengelola usahatani sejak kecil dan memiliki kepercayaan bahwa apa yang diajarkan secara turun-temurun itu sudah benar. Hal ini mempengaruhi sikap petani cenderung untuk menolak untuk mengadopsi informasi dan teknologi baru. Hal ini sejalan dengan pendapat Martin et al. (2016) menyatakan bahwa petani kecil cenderung tidak mengadopsi praktik baru yang tidak sesuai dengan tradisi pertanian mereka, karena mereka menghindari risiko kegagalan. Hal ini juga terlihat dari interaksi petani kopi dengan sumber informasi seperti penyuluh, pedagang dan kelompok tani masih rendah. Kondisi dilapangan terlihat semakin lama pengalaman petani dalam berusahatani kopi, belum cukup bisa untuk meningkatkan kompetensi petani dalam hal pengembangan usaha kopi.

Analisis data Tabel 2. menunjukkan bahwa penerimaan kopi berhubungan nyata dan positif dengan kompetensi petani dalam mengembangkan usaha kopi. Hal ini berarti bahwa semakin tinggi penerimaan petani, maka semakin tinggi kompetensi petani dalam pengembangan usaha kopi. Kondisi dilapangan terlihat bahwa petani kopi sukses yang memiliki penerimaan lebih tinggi dari petani lainnya, juga memiliki kemampuan mengolah kopi dan memasarkan hasil kopi lebih baik. Sebagian besar petani sukses merupakan pedagang pengumpul kecil, sehingga mereka memiliki hubungan baik dengan tengkulak. Petani pengumpul mendapatkan keuntungan kurang lebih Rp 3.000,- per kg kopi. Petani kopi sukes sudah menjual produk olahan bubuk kopi, namun hanya kalau ada yang memesan kopi bubuk saja. Mereka memiliki motivasi tinggi untuk berinovasi, seperti menjual kopi seduh dengan gula aren gigit di tempat wisata desa Keseneng. Petani sukses di Desa Keseneng merupakan petani tua yang memiliki pengalaman usahatani kopi realtif lama. Menurut Zainura et al. (2016), petani yang memiliki motivasi kurang dalam kewirausahaan, kurang termotivasi dalam melakukan inovasi pengembangan usahataninya disebabkan oleh umur petani yang kurang produktif.

Analisis data Tabel 2. menunjukkan bahwa keikutsertaan dalam kegiatan penyuluhan berhubungan nyata dan positif dengan kompetensi petani dalam mengembangkan usaha kopi. Hal ini berarti bahwa semakin tinggi keikutsertaan petani dalam kegiatan penyuluhan, maka semakin tinggi kompetensi petani dalam pengembangan usaha kopi. Hasil kondisi di lapangan bahwa sudah pernah ada kegiatan penyuluhan tentang budidaya kopi dan pembagian bibit unggul kopi. Penyuluhan tersebut dilakukan pada awal tahun 2000, dimana hasilnya petani yang mengikuti pelatihan dengan metode diskusi saat itu memiliki keinginan lebih tinggi dalam mengembangkan usahatani kopi daripada petani lain yang pasif dalam kegiatan penyuluhan. Hal ini sesuai dengan pendapat Nuryanti dan Swastika (2011), peran penyuluh diperlukan untuk memotivasi dan mengedukasi petani agar pantang menyerah dalam bekerja di sektor pertanian. Menurut Kusnani et al. (2015) yang menyatakan bahwa kegiatan penyuluhan yang dilakukan dengan metode diskusi dengan mengunjungi kelompok-kelompok sejenis yang lebih sukses menjadikan 
anggota kelompok lebih termotivasi dalam melakukan aktivitas di dalam kelompok.

Analisis data Tabel 2. menunjukkan bahwa interaksi sosial masyarakat perkebunan berhubungan nyata dan positif dengan kompetensi petani dalam mengembangkan usaha kopi. Hal ini berarti bahwa semakin tinggi interaksi sosial masyarakat perkebunan, maka semakin tinggi kompetensi petani dalam pengembangan usaha kopi. Kondisi dilapangan terlihat petani yang memiliki intersaksi sosial dengan penyuluh, pedagang dan antar petani baik merupakan petani kopi sukses. Petani kopi sukses dapat mengakses informasi dan teknologi lebih banyak, sehingga memiliki kompetensi dalam mengembangkan usaha kopi lebih baik pula. Hal ini sesuai dengan pendapat Anantanyu (2011), melalui interaksi yang dilakukan antar individu dalam masyarakat terjadi proses pembelajaran yang mampu meningkatkan kapasitas individu.

\section{KESIMPULAN DAN SARAN}

\section{Kesimpulan.}

Berdasarkan hasil penelitian diatas dapat disimpulkan bahwa petani kopi di Desa Keseneng memiliki kompetensi dalam pengembangan usaha kopi pada kategori sedang, dimana petani mampu mengolah hasil kopi menjadi produk kopi bubuk dan memiliki inovasi menjual kopi seduh gula aren gigit di tempat wisata Desa Keseneng. Hasil analisis menunjukkan peubah pendidikan formal dan pengalaman petani tidak berhubungan nyata dengan kompetensi petani dalam mengembangkan usaha kopi. Peubah penerimaan kopi $(0,751)$ dan keikutsertaan dalam kegiatan penyuluhan $(0,794)$ berhubungan nyata dan positif dengan kompetensi petani pada tingkat keeratan hubungan sangat kuat. Peubah interaksi sosial masyarakat perkebunan $(0,713)$ berhubungan sangat nyata dengan kompetensi petani pada tingkat keeratan hubungan kuat.

\section{Saran.}

Sebaiknya petani meningkatkan keikutsertaan dalam kegiatan penyuluhan dan interaksi sosial dengan masyarakat perkebunan dalam rangka meningkatkan akses informasi dan teknologi untuk pengembangan usaha kopi.

\section{DAFTAR PUSTAKA}

Allen, H. F., M. M. Batubara, dan H. Iswarini. 2015. Kendala penyuluh dalam melaksanakan aktivitas penyuluhan pada usahatani kopi di Kecamatan Dempo Utara Kota Pagar Alam. J. Societa. 4 (2): 105-110.

Anantanyu, S. 2011. Kelembagaan petani: peran dan strategi pengembangan kapasitasnya. SEPA. 7 (2): 102-109.

Azwar, S. 2012. Penyusunan Skala Psikologi edisi 2. Pustaka Pelajar, Yogyakarta.

Badan Pusat Statistik. 2018. Jumlah Produksi Tanaman Perkebunan Rakyat di Kabupaten Semarang 2017.

Dufour, B.P., Kerana, I.W., Ribeyre, F., 2019. Effect of coffee tree pruning on berry production and coffee berry borer infestation in the Toba Highlands (North Sumatra). Crop Protection 122, 151-158. https://doi.org/10.1016/j.cropro.2019.0 5.003

Durand-Bessart, C., Tixier, P., Quinteros, A., Andreotti, F., Rapidel, B., Tauvel, C., Allinne, C., 2020. Analysis of interactions amongst shade trees, coffee foliar diseases and coffee yield in multistrata agroforestry systems. Crop Protection 133, 105137. https://doi.org/10.1016/j.cropro.2020.1 05137

Eanes, F.R., Singh, A.S., Bulla, B.R., Ranjan, P., Fales, M., Wickerham, B., Doran, P.J., Prokopy, L.S., 2019. Crop advisers as conservation intermediaries: Perceptions and policy implications for relying on nontraditional partners to increase U.S. farmers' adoption of soil and water conservation practices. Land Use Policy 81, 360-370. https://doi.org/10.1016/j.landusepol.20 18.10.054 
Escola, J.P.L., Guido, R.C., da Silva, I.N., Cardoso, A.M., Maccagnan, D.H.B., Dezotti, A.K., 2020. Automated acoustic detection of a cicadid pest in coffee plantations. Computers and Electronics in Agriculture 169, 105215.

https://doi.org/10.1016/j.compag.2020. 105215

Fischer, K., Sjöström, K., Stiernström, A., Emanuelson, U., 2019. Dairy farmers' perspectives on antibiotic use: A qualitative study. Journal of Dairy Science 102, 2724-2737. https://doi.org/10.3168/jds.2018-15015

Hong, Z., Sun, Y., 2020. Power, capital, and the poverty of farmers' land rights in China. Land Use Policy 92, 104471. https://doi.org/10.1016/j.landusepol.20 20.104471

Huang, J., Pan, J., Zhou, L., Zheng, D., Yuan, S., Chen, J., Li, J., Gui, Q., Lin, W., 2020. An improved double-row rubber (Hevea brasiliensis) plantation system increases land use efficiency by allowing intercropping with yam bean, common bean, soybean, peanut, and coffee: A 17-year case study on Hainan Island, China. Journal of Cleaner Production 263, 121493. https://doi.org/10.1016/j.jclepro.2020.1 21493

Kurniawan, R., dan B. Yuniarto. 2016. Analisis Regresi Dasar dan Penerapanya dengan R. Kencana, Jakarta.

Kusnani, D. K., P. Muljono, dan A. Saleh. 2015. Dinamika kelompok penerima csr pln tarahan Lampung Selatan. J. Penyuluhan. 11 (2): 129-142.

Mahyuda, S. Amanah, dan P. Tjitropranoto. 2018. Tingkat adopsi good agricultural practices budidaya kopi arabika gayo oleh petani di Kabupaten Aceh Tengah. J. Penyuluhan. 14 (2): 308323.

Malta. 2016. Faktor-faktor yang berhubungan dengan kemandirian petani dalam pengambilan keputusan untuk keberlanjutan usahatani. 18 (2): 118124.

Manyamsari, I., dan Mujiburrahmad. 2014. Karakteristik petani dan hubungannya dengan kompetensi petani lahan sempit. J. Agrisep. 15 (2): 58-74.

Martin, E., D. Suharjito, D. Darusman, S. Sunito, dan B. Winarno. 2016. Etika subsistensi petani kopi: memahami dinamika pengembangan agroforestri di dataran tinggi Sumatera Selatan. J. Sosiologi Perdesaan. 92-102.

Meliasari, E. Soetarto, dan M. Shohibuddin. 2017. Hubungan kondisi sosialekonomi rumah tangga dengan minat pemuda desa di bidang pertanian. J. Sains Komunikasi dan Pengembangan Masyarakat. 1 (4): 523-536.

Meylan, L., Gary, C., Allinne, C., Ortiz, J., Jackson, L., Rapidel, B., 2017. Evaluating the effect of shade trees on provision of ecosystem services in intensively managed coffee plantations. Agriculture, Ecosystems \& Environment 245, 32-42. https://doi.org/10.1016/j.agee.2017.05. $\underline{005}$

Muhibuddin, S. Amanah, dan D. Sadono. 2015. Tingkat kompetensi petani agribisnis sayuran pada lahan sempit di kota Banda Aceh dan kabupaten Aceh Besar. J. Penyuluhan. 11 (2) : 186-200.

Nazaruddin dan O. Anwarudin. 2019. Pengaruh penguatan kelompok tani terhadap partisipasi dan motivasi pemuda tani pada usaha pertanian di Leuwiliang, Bogor. J. Agribisnis Terpadu. 12 (1): 1-14.

Nuryanti, S., dan D. K. S. Swastika. 2011. Peran kelompok tani dalam penerapan teknologi pertanian. Forum Penelitian Agro Ekonomi. 29 (2): 115-128.

Peraturan Menteri Pertanian Nomor 49/Permentan/OT.140/4/2014 tentang Pedoman Teknis Budidaya Kopi yang Baik 
Pertiwi, P. R., dan A. Saleh. 2010. Persepsi petani tentang saluran komunikasi usahatani padi. J. Komunikasi Pembangunan. 8 (2): 46-61.

Pratiwi, R. R. 2016. Hambatan dan strategi pengembangan usahatani kopi dalam upaya peningkatan produksi. J. Analisis Ekonomi. 5 (2): 207-216.

Priantara, I. D. G. Y., S. Mulyani, dan I. K. Satriawan. 2016. Analisis nilai tambah pengolahan kopi arabika Kintamanibangli. J. Rekayasa dan Manajemen Agroindustri. 4 (4): 33-44.

Purnawanto, B. 2010. Manajemen SDM Berbasis Proses: Pola Pikir Baru Mengelola SDM pada Era Knowledge Economy. PT. Gramedia, Jakarta.

Rayuddin. 2010. Pengembangan kompetensi agribisnis petani kakao di kabupaten Konawe provinsi Sulawesi Tenggara. Disestasi. Institut Pertanian Bogor.

Reijntjes, C., B. Haverkort., dan A. W. Bayer. 2011. Pertanian Masa Depan. Kanisius, Yogyakarta.

Robbins, S. P. dan T. A. Judge. 2008. Perilaku Organisasi Edisi 12. Salemba Empat, Jakarta.

Romano. 2009. Kajian sistem agribisnis kopi organik di daerah pegunungan Gayo. J. Aplikasi Manajemen. 7 (1): 21-33.

Santamaría, C., Lachaud, J.-P., Armbrecht, I., 2020. Effects of nest building by the dominant hunting ant, Ectatomma sp. 2 (E. ruidum complex), on Andean coffee plantations. Pedobiologia 79, 150626.

https://doi.org/10.1016/j.pedobi.2020.1 50626

Sosa-Aranda, I., del-Val, E., HernándezMartínez, G., Arroyo-Lambaer, D., Uscanga, A., Boege, K., 2018. Response of lepidopteran herbivore communities to crop management in coffee plantations. Agriculture, Ecosystems \& Environment 265, 37-
44.

https://doi.org/10.1016/j.agee.2018.05. $\underline{018}$

Suprayitno, A. R., Sumardjo, D. S. Gani., dan B. G. Sugihen. 2012. Motivasi dan partisipasi petani dalam pengelolaan hutan kemiri di kabupaten Maros provinsi Sulawesi Selatan. J. Penyuluhan. 9 (2): 182-196.

Tsai, D.-M., Chen, W.-L., 2017. Coffee plantation area recognition in satellite images using Fourier transform. Computers and Electronics in Agriculture 135, 115-127. https://doi.org/10.1016/j.compag.2016. $\underline{12.020}$

Vicol, M., Neilson, J., Hartatri, D.F.S., Cooper, P., 2018. Upgrading for whom? Relationship coffee, value chain interventions and rural development in Indonesia. World Development 110, 26-37.

https://doi.org/10.1016/j.worlddev.201 $\underline{8.05 .020}$

Waris, N. Badriyah, dan W. A. Dyah. 2015. Pengaruh tingkat pendidikan, usia, dan lama beternak terhadap pengetahuan manajemen reproduksi ternak sapi potong di Desa Kedungpring Kecamatan Balongpanggang 1 Kabupaten Gresik.

Yuantari, M. G. C., B. Widiarnako, dan H. R. Sunoko. 2013. Tingkat Pengetahuan Petani dalam Menggunakan Pestisida. Prosiding Seminar Nasional Pengelolaan Sumberdaya Alam dan Lingkungan. 142-148.

Zainura, U., N. Kusnadi, dan Burhanuddin. 2016. Perilaku kewirausahaan petani kopi arabika gayo di Kabupaten Bener Meriah provinsi Aceh. J. Penyuluhan. 12 (2): 126-143.

Zakaria, A., P. Aditiawati, dan M. Rosmiati. 2017. Strategi pengembangan usaha tani kopi arabika. J. Sosioteknologi. 16 (3): 325-339. 